\title{
ДИГИТАЛНА ХУМАНИСТИКА И ЊЕНА ПРИМЕНА У ОДЕЉЕЊУ ЗА УМЕТНИЧКУ ДОКУМЕНТАЦИЈУ МУЗЕЈА САВРЕМНЕ УМЕТНОСТИ У БЕОГРАДУ
}

\section{Сажетак}

Тежиште рада биће на појму дигиталне хуманистике, њеном дефинисању и примени у култури са освртом на пројекат "Читајте о...".

Дигитална хуманистика представља ново подручје рада које еволуира из рачунарске хуманистике. Иако њена дефиниција још није јасно прецизирана, може се уочити намера да се истражи утицај дигиталног на хуминистичко, као и да се анализира њихово међусобно прожимање. Важност дигиталне хуманистике у оквиру различитих пројеката у култури је велика јер омогућава стварање дигиталних ресурса у култури, лаку и брзу приступачност подацима, као и релационо повезивање различитих културних образаца. Све то омогућава реализацију крупних пројеката, који могу квалитетно кроз међусобну сарадњу да утичу на одређене друштвене и техничке изазове. Важност дигиталне хуманистике је у односу који се успоставља између израде концепата и њиховог имплементирања у пракси, обзиром да се ствари у пракси много теже реализују него у теорији. На крају се може закључити да је дигитална хуманистика та која поставља изазове хуманистичким наукама.

Одељење за уметничку документацију Музеја савремене уметности у Београду већ дуже време, у оквиру пројекта "Читајте о" дигитализује свој специфичан фонд о уметницима. Дигитализовани су: изложбени каталози уметника, чланци из новинске штампе и стручне периодике, фотографије са изложби, а савки уметник је хронолошки и биографски представљен. Пројекат је настао из потребе да се фонд библиотеке Музеја учини што приступачнијим истраживачима, студентима, ђацима и љубитељима уметности. Идеја је била да се у електронској читаоници представе библиографије различитих уметника и уметничких појава са простора бивше Југославије које поседује Музеј савремене уметности. У оквиру овог пројекта, који је започет 2009. године, урађено је пет читаоница. Приликом рада сусретали смо се са разним проблемима у вези дигитализације и имплементације грађе, ауторских права, новчаних средстава и др.

Настојаћемо да у раду прикажемо начин израде читаоница, са освртом на практичне проблеме са којима смо се сусретали, као и да истакнемо зашто је њихов садржај битан за савремену културу. Посебан нагласак биће на последњој 
читаоници "Читајте о Надежди Петровић" јер се ове године навршава 100 година од смрти ове истакнуте уметнице.

Кључне речи: дигитална хуманистика, пројекат, читаоница, библиотека, Музеј савремене уметности, Одељење за уметничку документацију, уметност, култура

\section{Увод}

Фредерик Ј.Френд (Friend, 2015), каже, да је историја људске цивилизације историја развоја, и да свака генерација учи на искуству ранијих генерација, при чему и сама доприноси даљем развоју цивилизације својим радом и знањем. Учимо на достигнућима и неуспеху претходних генерација, на искуствима својих родитеља у прошлости, као и од наших учитеља, друштва у којем живимо. У том процесу учења библиотеке имају веома значајну улогу. Оне чуваји и штите писану историју и меморишу достигнућа наше цивилизације, која тако постаје основа будућег развоја. Људи су одувек посећивали библиотеке. Било је веома битно да се зна да је она увек ту када нам затреба. С обзиром да сада људи имају много мање слободног времена за посете библиотекама, библиотекари настоје да им максимално олакшају приступ информацијама. Данас се тражи брзина, мултимедијалност, достпуност и претраживост разних садржаја. Многе библиотеке дигитализују своје садржаје и омогућавају корисницима директан (онлајн) приступ информацији. Библиотека Музеја савремене уметности је део свог фонда дигитализовала и тако омогућила истраживачима и другим корисницима, да директно користе податке који су им потребни у раду, без обзира на време и место где се налазе.

У овом раду ћемо покушати да објаснимо појам дигиталне хуманистике као и њену примену у Одељењу уметничке документације.

\section{Појам хуманистике и дигиталне хуманистике}

На самом почетку би требало разјаснити основне појмове и разлике између хуманистике, и дигиталне хуманистике. 
Хуманистика се бави откривањем, очувањем и интерпретацијом културне баштине. Предмети истраживања су обично објекти који се данас чувају у баштинским установама. У њих се убрајају: теологија, историја, историја уметности, филозофија, књижевност и књижевна критика, филологија, археологија, и оне су незамисливе без писаног текста, независно од тога у ком је формату. Временом је дошло до промене парадигме истраживања у хуманистичким наукама. Доста тога је утицало на те промене. Хуманистичке науке нису више уско везане за једну дисциплину. Промене захтева истраживача, продор квантитативних истраживачких метода као и појава информационих технологија крајем 20. века, доводи до настанка дитигалне хуманистике.

Она је заправно једно ново подручје рада које еволуира из рачунарске хуманистике. Њено дефинисање није јасно прецизирано. Једна од конкретнијих дефиниција је да је њен циљ истраживање утицаја дигиталног на хуминистичко, као и анализа њиховог прожимања. Сматра се да је дигитална хуманистика та која поставља изазове хуманистичким наукама.

Поставља се питање зашто је она важна? Чињеница је да дигитална хуманистика омогућује велике пројекте, кроз разне врсте сарадњи, и може много квалитетније одговорити на одређене друштвене и техничке проблеме. Ствари се много теже постављају у пракси него у теорији.

Дигитална хуманистика је област у настајању, посвећена је истраживањима и примени информатичких метода и технологија у хуманистичким наукама. Дигиталне хуманистичке науке обухватају нове дигитализоване материјале, као и оне који су касније дигитализовани и комбинује методологије разних друштвених дисциплина са алатима које пружа информатика и дигитално издаваштво.

\section{Историјат и почеци}

Сама дигитална хуманистика има веома занимљиву историју. Рачунарска технологија је постала основни предуслов да би се размишљало о великом броју питања у хуманистичким наукама (Digital Humanities Manifesto 2.0). 
Први талас у дигиталној хуманистици био је квантитативан. Мобилисао је могућност базе података за претраживање и извлачење података, аутоматизовао корпусну лингвистику, слагао критичке хиперкартице у критичке низове.

Други талас је квалитативан, интерпретативан, емпиријски, емоционалан, генеративан по карактеру. Он дигиталне комплете алата ставља у службу основних методолошких предности хуманистичких наука: обраћање пажње на сложеност, специфичност медијума, историјски контекст, аналитичку дубину, критику и тумачење. (Schnapp i Presner, 2009)

Према Преснеру, први талас дитигалних хуманистичких наука се појавио деведестих година прошлог века и већ почетком овог века је концентрисан на велике пројекте дигитализације и профилисан на анализу текста, у оквиру постојећих дисциплина. Тај први талас, који се може назвати и "Хуманистичко рачунарство", је у ствари представљало изградњу инфраструктуре у проучавању текстова хуманистичких наука кроз разне дигиталне архиве. Док други талас назван "Дигитална хуманистика 2.0", уводи нове дисциплине, нове парадигме, методологије, па и нове моделе издаваштва. Он у ствари шири границе архива хуманистичких наука, као и алата за проучавање нових дигиталних материјала, као што су електронске књиге и др. И на крају трећи талас, који показује начин на који дигитална технологија истиче аномалије које настају у неком истраживачком пројекту у хуманистичким наукама и које води преиспитивању претпоставки које су укључене у таквом истраживању.

На крају би се могло рећи да дигитална хуманистика у ствари спашава хуманистичке науке, које су остале у великој мери у својим старим оквирима.

\section{План дигитализације}

Планирање процеса дигитализације је веома битно. Полази се од постављања циљева, претпоставки потреба корисника, метода, поступка, па све до одабира технике, опреме, обучавања кадра, из- 
вора финансирања, које доприносе остваривању крајњег циља. Не постојање плана дигитализације обично води губитку како новца, информација тако и драгоценог времена.

Процес дигитализације, па самим тим и развој дигиталне хуманистике, не битребалодазависи од ентузијазма појединца, финансијских предности појединих институција, добре воље локалне самоуправе, као и привлачности појединих пројеката. Дигитализација културне баштине представља суштину националне свести, као и очувања од пропадања. Овај процес треба водити смислено и плански.

\section{Циљеви}

Дигиталне хуманистичке науке имају више циљева. Један од њих је укључење компјутерске технологије у рад научника из области хуманистичких наука, тако што ће употребити различите техничке анализе, система за управљање информацијама из разних области. Циљеви су такође и стварање академских радова који су више од текста и папира. То подразумева имплементацију мултимедијалних информација, метаподатака и др. Повећан је обим важних академских радова у дигиталним хуманистичким наукама. 3бог тога је све више истраживача хуманистичких наука који користе рачунар за анализу база података из области културе. Многима помаже да одговоре на већ постојећа истраживачка питања, да дођу до нових примера или да размене искуства.

\section{Одељење за уметничку документацију у дигиталном окружењу}

Дигитализација грађе има огроман значај за очување културне и научне баштине једног народа. Прво, на тај начин се чувају од губитка или случајног уништења драгоцени уникатни записи, фотографије, ретки материјали и информације са разних класичних медија (грамофонских плоча, филмова, трака, мапа, књига, итд). Такође, диги- 
тализована баштина може се ставити на располагање великом броју корисника, који не морају бити физички на истој локацији. Чувајући културну баштину чувамо и сећање на све оно шта је било пре нас. Сећајући се, ми учествујемо у прошлости преко које креирамо сопствену будућност. Само доступношћу културног блага заинтересованима, сада и у будућности, могуће је очувати историјски и културни идентитет једне нације (Настић 2012: 111-131).

Пројекат "Читајте о" Одељења за уметничку документацију представља добар пример где се садржаји једне хуманистичке дисциплине представљају на интернету. Пројекат је настао из потребе да се фонд библотеке учини приступачан истраживачима. "Читаjme о..." је електронска читаоница у којој се налазе најкомплетније библиографије уметника и уметничких појава са простора бивше Југославије. У њој су систематски прикупљени, обрађени и дигитализовани: каталози, делови књига, часописа, фотографија, видео записа, новинских текстова и све је то постављено на интернет (WEB страница Музеја) где заинтересовани могу да им приступе.

Пројектом је предвиђено да се прате различите теме у електронском окружењу. Реализација је започета 2009. године. До сада је постављено пет електронских читаоница (које се стално допуњавају новим садржајима): о Петру Лубарди, Музеју савремене уметности, Сави Шумановићу, Надреализму и Надежди Петровић. Материјал који чини електронску читаоницу већим делом је из фонда који поседује библиотека и за уметничку документацију Мсу. Поједину грађу смо преузимали, уз дозволу других институција. Приликом рада сусретали смо се са разним проблемима који су се односили на дигитализацију и имплементацију грађе, ауторска права, новчана средстава и друге препреке.

Радећи на електронским читаоницама покушали смо да поставимо форму читаонице која ће се на једноставан начин пунити новим кључним садржајима (текстовима). У погледу садржаја, читаонице су од почетка биле добра подлога за програме које организује МСУ. Касније су теме проширене према потребама и комплексности материјала који поседује Одељење за уметничку документацију МСУ. Предност интернета је овде дошла до пуног 
изражаја, јер омогућава лак и брз приступ сваком тексту и брзу размену информација. Међутим, интернет често кроз појаву хипертекстуалности и интеракције преко различитих линкова води у бројне правце истраживања што може да отежа оријентисање самих истраживача у виртуалном смислу. Зато је читаоница од свог формирања јасно и тачно дефинисана и систематично организована ка брзом и лаком приступу траженим садржајима. Нас је ова промена у самом приступу текстовима као и његовој употреби навела да започнемо са другачијом организацијом и презентацијом садржаја које чува Одељење за уметничку докумнтацију МСу. Тежња да се потпомогну истраживања и да се другим средствима успостави однос између садржаја (теме истраживања) и алата којим се лако и брзо долази до података (рачунара, претраживача) постепено је реализована. На овај начин се место историје и уметности у данашње време битно променило у односу самог корисника садржаја и садржаја који му је доступан. До сада је правац употребе текста имао два сегмента, а то је текст и читалац коме се тај текст нуди. Појавом нових информационих технологија, нарочито интернета, између корисника и текста као неизбежан елемент се појављује рачунар са одговарајућим софтвером уз чију помоћ се могу проналазити, визуелизовати и користити тражени садржаји. Тако се сваки садржај у било ком дигиталном формату (JPG, PDF, DOC, MP3, MP4, MOV,.. и др.) једним кликом уз одговарајући софтвер може прегледати, повећати, копирати, достављати.

Одељење за уметничку документацију и библиотека МСУ поред књига чува и специфичну библиотечку грађу попут: изложбених каталога бројних изложби са ових простора и пресклипинг - приказ у штампи активности везаних за уметност у време дешавања тог догађања. Управо је то био повод да се овако драгоцен материјал издвоји, сачува у другом облику и да се омогући његова већа доступност и размена. У фонду библиотеке се налазе каталози изложби из читавог региона, с обзиром да је МСУ од свог формирања био центарална институција за савремену уметност на простору Југославије. Тако су и данас многи текстови и публикације из нашег фонда кључне за бројне истраживаче из региона и шире. Такође у библиотеци се 
могу читати критике и чланци разних изложби чиме се уједно може пратити и хроника уметничког живота Југославије и Србије. Због тога је, увиђајући значај овог фонда, покренут пројекат у коме је требало да се нађу и сачувају најзначајнији текстови о уметницима и појавама у модерној и савременој уметности.

\section{Пројекат: реализација}

Упоредо са прославом јубилеја посвећеног рођењу Петра Лубарде МСУ је организоао велику ретроспективну изложбу на којој је постављена прва електронска читаоница о овом истакнутом уметнику (Читајте о Петру Лубарди, 2015). Идеја је била да се прикупи комплетна библиографска грађа која ће се пописати, дигитализовати и постати свима доступна. Важно је истаћи да су се међу дигитализованим каталозима нашли и кључни изложбени каталози овог уметника ${ }^{1}$. Сам процес рада на читаоници захтевао је велики ангажман. Електронска форма читаонице је успостављена према организацији материјала у Одељењу за уметничку документацију. Издвојене су целине: изложбени каталози, књиге, периодика и хемеротека (пресклипинг). Оваква форма задржала се до данас са извесним унапређењима. Уведен је сегмент фотодокументације и систем претраге.

Друга по реду је била читаоница о уметнику Сави Шумановићу (Читајте о Сави Шумановићу, 2015) која је покренута са циљем да се прво дигитализују сви самостални изложбени каталози овог значајног уметника. С обзиром да Одељење за уметничку документацију не поседује све каталоге овог уметника у раду је била драгоцена сарадња са Архивом за ликовне умјетности ХАЗУ који нам је уступио дигитализоване каталоге изложби Саве Шумановића.

У периоду када је Музеј савремене уметности затворен за јавност услед реконструкције јавила се потреба за једном новом темом - Музејом савремене уметности (Читајте о Музеју савреме-

1 Попут каталога изложбе из 1951. који је означио преломни тренутак у савременој уметности југословенског уметничког простора. http://www.citajteo.rs/slika.php?id_ zapisa=3\&tip=KD\&deo=1. 08.09.2015. 
не уметности, 2015). Иако је Музеј имао своје место у виртуелном окружењу тако да су корисници могли да се информишу о његовим програмима и активностима путем WEB странице покренули смо и нову тему која ће се бавити историјатом ове институције. Поред тога што је свих ових година реконструкције, Музеј активно спроводио своје планиране програме и библиотека је била отворена за посетиоце и истраживаче. Идеја је била да ова тема читаоце на посредан начин информише о настанку, политици излагања, изградњи зграде, а непосредно да се истакну историјске, друштвене и културно-уметничке особености југословенског простора и односа друштва према савременој уметности XX века. Увидели смо да дигитализација овакве грађе може бити добар едукативни модел, компарације некадашњег и садашњег тренутка. Музеј савремене уметности је одувек био актуелна тема којом су се бавили многи истраживачи како због непроцењивог наслеђа које чува, тако и због свог јединственог архитектонског простора. Пројекат је подразумевао дигитализацију: текстова и књига, каталога, чланака и документаристичких фтографија који се односе на оснивање и историјат МСУ. Интересовање које су истраживачи током времена показали према овој теми искристалисао је идеју да се у њој нађу најтраженија издања МСУ попут каталога Југословенска уметност XX века. Наведена издања су од велике важности јер је у њима евидентиран, репродукован и каталогизован велики број експоната из културног наслеђа Југосавије. Поред тога дигитализоване су и монографске изложбе уметника у Салону, музејске монографије, водичи и др. Посебна новина је одељак за фотодокументацију. Фотодокументи су уједно и најупечатљивија сведочанства о одређеним битинм догађајима у историји Музеја савремене уметности. Фото грађа је претежно била у облику негатива који су електронски обрађени и на крају имплементирани у читаоницу, у одељак за фотодокументацију. Дефинисан је и посебан систем претраге како би се брже и лакше могло доћи до траженог податка. Текстови који се нуде у оваквим дигиталним базама, омогућавају корисницима да се на једноставан начин, кроз целине које су предходно формиране, фокусирају на тражене садржаје. Захваљујући тако постављеним елементима добијамо јасну слику о материјалу који 
чува библиотека МСУ. Истраживачи и корисници могу само једним притиском на миша ући у жељени садржај, који могу да прегледају и по потреби копирају. Тако се опет успоставља однос по коме се истраживачево место измешта у једно ново окружење у коме се преко датих целина може лако пратити хронологија догађаја који су се дешавали у музеју.

Увиђајући значај теме која се односила на авангардне појаве прве половине 20. века у Србији, покренута је електронска читаоница о историјским авангардама (Читајте о Авангради, 2015). До данас су дигитализовани поједини авангардни часописи као и књиге надреалистичких издања које се налазе у библиотеци МСУ. На изложби одржаној у Музеју савремене уметности у Београду 1969. године стваралаштво српских надреалиста је први пут реконструисано, проучено и изложено као целина. Каталог који је пратио ову изложбу веома је битан за истраживање о надреализму и доступан је у електронском облику (Читајте о...).

Последњи велики пројекат на коме се ради је електронска читаоница посвећена Надежди Петровић (Читајте о Надежди Петровић, 2015). Читаоница треба да истакне значај и обележи 100 година од смрти ове исткануте сликарке и кључне личности у уметности са почетка XX века. Сазнања о уметници читалац добија у електронској форми прегледом различитих текстова, критика, чланака, каталога. На овај начин се отварају и померају границе приступа тексту и информацијама корисницима и истраживачима у овој области. Дигиталне технологије постају саставни део савремених истраживања при чему се природа истраживачког рада битно мења. У читаоници је своје место нашао дигитализован материјал који се односи на уметност Надежде Петровић. Читаоница заправо представља базу података која се чита као велика библиографија са визуализованим текстовима. Сваки текст може да се погледа у PDF електронском формату и као такав преузме. Предност оваквих база је могућност њихове сталне допуне и дораде јер нови медији то омогућују.

Овакве базе података подстичу нову рецепцију уметности у садашњем реалном окружењу. Међутим, овакви и слични садржаји о уметности који се могу пронаћи на интернету више су оријентисани ка 
стручној јавности, па се још увек не може говорити о популаризацији оваквих тема, што их то на неки начин чува од глобалног популарног тржишта. Пројектима који се баве дигитализацијом културног наслеђа успостављају се критеријуми презентације и конзумирања садржаја на интернету. Због тога је важност садржаја и његов одабир у ери дигиталне културе веома битан. Избор садржаја је посебно важан елемент пројекта "Читајте o". Он настаје из стручних анализа и сагледавања важности одређене теме, као и интереса самих истраживача.

\section{Закључак}

На крају можемо закључити да је интерактивност између дигитализованих садржаја и корисника кључна, јер се са њом дистрибуирају садржаји и тако повећава њихова видљивост. Веома је битно да различити пројекти, који се баве сличним темама и који своје садржаје чине доступним кроз интерент, уједине настојања ка стварању глобалне мреже за културу и уметност. До сада су чести пропусти били у комуникацији међу покретачима пројеката, па се не ретко дешавало да се исти садржаји дигитализују на више места чиме су се трошили време, новац и ресурси. Међутим добрих примера има, они су пронашли своје место на глобалној мрежи дигитализоване културне баштине. Оправдане су тврдње појединих заговорника теме да дигитална хуманистика треба да тежи унапређењу система дигитализације, као и да дигитализоване књиге треба да буду преведене у лакше претраживе облике од фотографија (скенова) које су дате. Међутим, сваки корак у дигитализавији је важан јер представља добру иницијативу да се културна баштина коју чувају музеји, библиотеке или архиви може представити и на интернету. Дигитализација и технолошки напредак омогућили су да се на једноставан начин дође до жељених информација коришћењем рачунара, мобилних телефона, таблета... Технолошке иновације мењају дисциплинарни дискурс хуманистичких наука, оне представљају добар покушај да се створе услови који ће унапредити разумевање културе на глобалном нивоу. 


\section{Литература}

Вранеш, Александра. "Дигитална хуманистика и савремене библиотеке". Инфотека: часопис за информатику библиотекарство, год.15, бр.1 (2014): 4-14.

Digital Humanities Manifesto 2.0, http://www.humanitiesblast.com/manifesto/Manifesto_ V2.pdf. 21.07.2015.

Дигитална страна музеја. ICOM : часопис националног комитета националног савета Музеја - Србије, бр.3 (децембар 2013): 40,42, 57, 59,61,63.

http://network.icom.museum/fileadmin/user_upload/minisites/icom-serbia/pdf/ digitalna_strana_muzeja_2013.pdf.08.09.2015.

Манифест за дигиталне хуманистичке науке, http://tcp.hypotheses.org/503. 21.07.2015. Настић,Оливера, "Појам и значај дигитализације културне и научне баштине", У: 11. Међународна конференција „Дигитализација културне и научне баштине, универзитетски репозиторијуми и учење на даљину". Београд: Филолошки факултет, књ. 2, 2012. 111-131.

Тасовац, Тома. "DARIAH Reference Curriculum". Читалиuте, год. XIV, бр. 26 (мај 2015): 77-78. UCI School of Humanities, http://www.humanities.uci.edu/SOH/. 21.07.2015.

Friend, Frederick J., Mission and Purpose of Academic Libraries in the 21st Century, Scholarly Comunication Web site - University College London, http://www.ucl. ac.uk/scholarly-communication/articles/beij.htm. 21.07.2015

Центар за дигиталне хуманистичке науке, http://www.humanistika.org/. 08.09.2015. 4umajme o..., http://www.citajteo.rs/index-petar-lubarda.php. 08.09.2015.

4umajme o..., http://www.citajteo.rs/index-sava-sumanovic.php. 08.09.2015.

4umajme o..., http://www.citajteo.rs/index-muzej-savremene-umetnosti.php. 08.09.2015. Yumajme o..., http://www.citajteo.rs/index-avangarda.php .08.09.2015.

4umajme o..., http://www.citajteo.rs/slika.php?id_zapisa=1009\&tip=KD\&deo=1 08.09.2015. 4umajme o..., http://www.citajteo.rs/index-nadezda-petrovic.php . 08.09.2015. 


\author{
Katarina Krstić \\ Olivera Nastić \\ Belgrade, Museum of Contemporary Art
}

\title{
DIGITAL HUMANITIES AND ITS APPLICATION \\ IN THE DEPARTMENT OF ARTISTIC DOCUMENTATION OF MUSEUM OF CONTEMPORARY ART IN BELGRADE
}

\begin{abstract}
Summary
The focus of the work will be on the term digital humanities, its determination and application in culture with emphasis on the project "Read about...".

Digital Humanities represents a new area of work which evolves from the computational humanities. Although its definition is still not clearly specified, we can see the intention to explore the impact of digital on humanistic, as well as to analyze their interrelations. The importance of digital humanities in the framework of various projects in the culture is great because it allows the creation of digital resources in culture, easy and quick accessibility of data, relational linking different cultural patterns ... All of this allows the realization of larger projects, which may well through mutual cooperation to affect certain social and technical challenges. The importance of digital humanities is in relation which is being established between the creation of concept and its implementation in practice, given that things are in practice much harder to implement than in theory. At the end it can be concluded that the digital humanities is the one that sets challenges in the humanities.

Department of Art Documentation of the Museum of Contemporary Art in Belgrade for a long time, within the project " Read all about ", digitizes their specific fund of artists. They already digitized: exhibit catalogs of artists, newspaper and periodicals articles, photographs of the exhibitions. Every artist is presented chronologically and biographically. The project was created from need to make fund of the library of the Museum more accessible to researchers, students and art lovers. The idea was to present in the electronic reading room bibliographies of various artists and artistic phenomena from the former Yugoslavia, which Museum of Contemporary Art in Belgrade has. In the framework of this project, which began in 2009, the five reading rooms were done.

During the work we met various problems related to digitization and implementation of materials, copyright, funds and other. We will try in this work to show the way in the work of making reading room, with emphasis on the practical problems we encountered, and to underline why content of reading rooms is essential for Contempo-
\end{abstract}


rary Culture. The emphasis will be on the last reading room "Read about the Nadezda Petrovic" because this year marks 100 years since the death of this distinguished artist.

Key words: digital humanities, project, reading room, library, Museum of Contemporary Art, Department of Art documentation, art, culture 